鼻アレルギーに対する炭酸ガスレーザー治療

一下鼻甲介 3 回蒸散法の治療成績一

今村 俊一・本田 英幸

\title{
Carbon Dioxide Laser Vaporization of Turbinate for Allergic Rhinitis
}

\author{
Shun-ichi Imamura and Hideyuki Honda \\ (Suwa Central Hospital)
}

\begin{abstract}
Carbon dioxide laser vaporization of turbinate has recently become accepted as a common treatment for allergic rhinitis. Usually, only a single irradiation is applied per outpatient clinic consultation to minimize trauma. However repeated irradiations on separate days are required to achieve an adequate effect. Therefore, we attempted a new method of vaporization and evaluated the outcome. To widely and deeply vaporize the inferior turbinate, irradiation was repeated three times in one session after removing the carbon coating from the previous irradiation under nasal endosopic observation. After the procedure, most patients experienced complete nasal obstruction for two or three days, but there was no intraoperative or postoperative bleeding. All patients had improvement of their chief complaints and were satisfied after a single treatment. Especially, $60 \%$ of the patients were completely released from refractory nasal obstruction.

Most patients were satisfied with the effects and the cost, compared with those treated by the usual methods. This method may be especially accepted by the patients with severe complaints, in particular nasal obstruction, but do not have enough time to make frequent visits to an outpatient clinic over a period of several weeks.
\end{abstract}

Key words : carbon dioxide laser, turbinate vaporization, allergic rhinitis

はじめに

近年各種の抗アレルギー剤の改良や開発により点鼻薬 や内服薬によるアレルギー性鼻炎症状のコントロールは 格段に進歩している112)．また初期治療2)3) が一般化する に従い，重症な花粉症患者も抗アレルギー剤の季節前内 服やステロイド剤などの点鼻薬の併用にて花粉症の季節 を乗り越えることができるようになってきている，その 一方, アレルギー性鼻炎患者は著明に増加し, 発症時期 の低年齢化, 重症化むみられ, 季節性抗原むマルチ化す ることによりほぼ 1 年中症状に苦しむ症例も少なくな (1)4)5).
従来より鼻閉に関しては内服, 点鼻薬による治療に限 界があるといわれている．近年ロイコトリエン拮抗薬な ど鼻閉の改善に効果を示す薬剤も開発され効果を上げて はいる ${ }^{6)}$ が，その一方下鼻甲介粘膜の慢性的な肥厚によ る慢性の鼻閉に苦しむ症例が数多く存在するのも事実で ある.

これまで薬剤治療にて症状の改善しない，特に鼻閉を 主訴とする頑固なアレルギー性鼻炎症例に対してはさま ざまな手術療法7) が考案され，一応の効果を上げてきた が，その侵襲の点などから必ずしも普及しているとはい えない。近年, 比較的取扱いが容易で術中の疼痛, 術後 
の出血などの危険性が少ない各種のレーザーによる下鼻 甲介の蒸散が盛んに行われ，その効果が報告されてい る ${ }^{8)}$ 10). 当院でも平成 11 年 11 月にレーザーシステム 導入後, 抗アレルギー剤, ステロイド剤の点鼻, 抗アレ ルギー剤, 抗ヒスタミン剂の内服により十分な症状の改 善が得られなかった重症な症例に対し, 炭酸ガスレー ザーによる下鼻甲介蒸散を施行し, 全般に良好な結果を 得ている.

当初, 外来にて 1 回蒸散した症例では症状改善が不十 分であったり, 効果の減弱, 消失が早く, 再治療を必要 とするケースもみられた。 この傾向は一般的にもみられ るようで, 外来にて日時を改めて複数回の施行を予定す

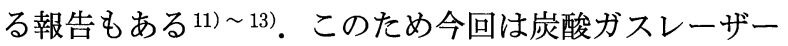
による下鼻甲介蒸散治療の手術としての有効性を再確認 するため, 入院の上，手術室で内視鏡を併用し，下鼻甲 介全体を 1 度に 3 回確実にレーザー蒸散することとした. また今回はレーザー治療以外の外科的治療を行った症例 は除外して，レーザー治療の術前術後の評価を行い分析 したので報告する.

\section{対象と方法}

対象：諏訪中央病院耳鼻咽喉科を受診し, 問診, 鼻腔 内所見，鼻汁中好酸球検查，MAST 等のいずれかにより アレルギー性鼻炎と診断され内服薬, 点鼻薬による治療 で十分な効果の得られなかった症例を対象とした，当初 は通年性アレルギー性鼻炎のみを対象としたが，患者の 希望により花粉症（スギ花粉症 6 例，その他 2 例）の患 者む対象とした．花粉症患者はスギ花粉症を中心に，少 なくとも 2 シーズン以上当科にて保存的治療を施行した 重症症例を対象とし,シーズン前の期間を選び施行した. 平成 11 年 11 月から 13 年 5 月までの間に, 上記の条件を 満たしたアレルギー性鼻炎患者 41 症例に対し，入院の 上，局所麻酔下に内視鏡下下鼻甲介レーザー治療を施行
した. なお今回の検討では鼻中隔矯正術，下鼻甲介切除 術などを併用した症例，外来にて従来どおり 1 回だけの 蒸散を行った症例は除外した。また術前術後に以下の評 価が施行し得なかった症例も除外した。

術前と術後にアレルギー性鼻炎の重症度分類（表 1） 14)15) を用いた問診による症状の評価と鼻腔通気度計 MPR2200（日本光電）による鼻腔通気度検查により鼻閉 の状態の変化を評価した。 また術後の自覚症状の変化と 満足度，手術に関してのアンケート調査を同時に行い集 計した。

41 症例の性別は男性 15 例，女性 26 例で，年齢は 11 〜 78 歳（平均 32.2 歳）であった。各症例の罹病期間は 最短で 2 年間, 最長で 30 年間で, 平均 7.6 年であった. アレルギーのタイプは通年性が 33 例 $(80 \%)$ で季節性 （スギを中心とする花粉症）が 8 例（20\%）であった.

手術方法:全症例とも手術約 30 分前に前投薬として硫 酸アトロピンとアタラックス $\mathrm{P}^{\circledR}$ の筋注を行った。局所 麻酔薬の局所注射は行わず，3000 倍希釈ボスミンと $4 \%$ キシロカインの等量混合液を浸したガーゼ（以下局所麻 酔ガーゼ）を鼻腔内に消毒，ドレーピング，剃毛の間留 置し表面浸潤麻酔を施行した，反対側の蒸散中は局所麻 酔ガーゼの留置を続け, 疼痛の訴えに応じて適宜延長し た. コンパクト $\mathrm{CO}_{2}$ レーザーシステム M-LASER MC100 （株式会社エム・アンド・エム）を用い細経アングルハン ドピース先端パイプ 45 度と 90 度を適時用いた。硬性内 視鏡に CCD カメラを接続しモニター上で観察しながら， 下鼻甲介後端まで可能な限りむらなく全面がカーボンで 覆われるまで蒸散した。いったん蒸散後に局所麻酔ガー ゼを再挿入，表面を擦過し，下鼻甲介に付着したカーボ ンを落とし, 蒸散の浅い部分を中心に再度蒸散を行った。 これを左右の鼻腔で 3 回ずつ繰り返し施行した．治療後 は鼻腔内にパッキングすることなく病棟へ帰室した．術 後 $1 \sim 2$ 日は鼻腔内の痂皮の除去，ネブライザー（ボス

表 1 アレルギー性鼻炎の重症度分類

（鼻アレルギー診療ガイドライン）

\begin{tabular}{|c|c|c|c|c|c|}
\hline & ++++ & +++ & ++ & + & - \\
\hline $\begin{array}{c}\text { くしゃみ } \\
\text { (1 日の発作回数) }\end{array}$ & 21 回以上 & $11 \sim 20$ 回 & $6 \sim 10$ 回 & $1 \sim 5$ 回 & 0 \\
\hline 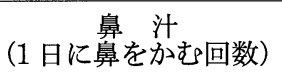 & 21 回以上 & $11 \sim 20$ 回 & $6 \sim 10$ 回 & $1 \sim 5$ 回 & 0 \\
\hline 鼻 閉 & $\begin{array}{l}\text { 1日中完全につまっ } \\
\text { ている }\end{array}$ & \begin{tabular}{|l} 
鼻閉が強く口呼吸が 1 \\
日うかなる
\end{tabular} & \begin{tabular}{|l|} 
鼻閉が強く 1 日のう \\
ち時々あり
\end{tabular} & $\begin{array}{l}\text { 口呼吸はないが鼻閉 } \\
\text { あり }\end{array}$ & 鼻づまりがない \\
\hline
\end{tabular}


ミン，ホスミシン，ステロイド剤含有）を施行した。術 後は抗生物質の点滴加療, 消炎剤の投与を行い, アレル ギーに対する術前の治療を継続した。

\section{結果}

手術に関して: 手術時間は最長でも 45 分程度で平均 30.1 分であった. 術後出血等のトラブルは皆無であった が，ほとんどの症例で術後 2,3 日間は下鼻甲介の腫脹, 泇皮形成による完全な鼻閉がみられた。このため連日の 局所処置, ネブライザーを施行した. 原則として入院当 日の午後に手術を行い2 日後に処置後退院としているが, 退院翌日の外来での処置をルーチンとしているため, 翌 朝の処置後の退院を希望する患者も多く入院期間の平均 は 3.7 日であった。術後の状態の評価は術後に痂皮形成 がみられなくなる約 1 カ月後に重症度分類を用いた症状 の確認と鼻腔通気度検查, レーザー治療に対するアン ケート（表 2）により行った.

症状の変化: 術前術後の症状の変化はアレルギー性鼻 炎の重症度分類によった。

まず，くしゃみに関して（図 1), 術前症状は段階 3 以 上 (1 日の発作回数 11 回以上) であった症例が 20 人 (49 \%) であったのに対し術後は 40 人（98\%）が 2 以下（1 日の発作回数 10 回以下) になっていた. 18 人 (43\%) で 2 段階以上の改善がみられており，平均でも 1.4 段階の 改善がみられている.

次に鼻汁に関して（図 2）は，術前症状が段階 3 以上 （1 日に鼻をかむ回数が 11 回以上）であった人が 35 人 （85\%）であったのに対し術後は 37 人（90\%）が 2 以下 （1 日に鼻をかむ回数が 10 回以下）に改善している. 24 人 $(59 \%)$ で 2 段階以上の改善がみられており, 平均で も 1.8 段階の改善がみられている.

鼻閉に関して（図 3）は，術前症状は段階 3 以上（鼻 閉が強く 1 日のらちかなり口呼吸以上) の人が 25 人 (61 \%) であったのに対し術後は全員が 2 以下（鼻閉が強く 1 日のうち時々口呼吸）になり，34人（83\%）は 1 以下 (口呼吸はないが鼻閉はある)，24人（59\%）は０（鼻閉 なし）に改善している. 29 人（71\%）で 2 段階以上の改 善がみられており, 平均でも 2.0 段階の改善がみられて いる. 症状の悪化はくしゃみにおいて 0 から 1 亿悪化し た症例が 2 症例あったがいずれも一時的なものでその後 は改善している.

鼻腔通気度の変化 : 術前の鼻腔通気度検査で 4 例が完
表 2 レーザー治療に対するアンケート

1. 痛みについて

質問 1. 手術中の痛み（局所麻酔の方）はいかがでしたか? 回答：かなり強い・多少痛い・ほとんど気にならない

質問 2. 術後の痛みはどらでしたか?

回答：かなり強い・多少痛い・ほとんど気にならない

2. 手術自体について

質問 1. 手術時間は思っていたのと比較していかがでした 回答: 長い・気にならない・短い

質問 2. 入院日数はいかがでしたか? 回答 : 長くてもよい・ちょうどよい・短い方がよい

質問 3. 費用は思っていたのと比較して 回答 : 高い・気にならない・安い

3. 術後落ちついてから現在の状態について

質問 1. 鼻閉の改善度はいかがですか? 回答：かなり良い・良い・変わらない・悪くなった

質問 2. 鼻水の改善度はいかがですか? 回答：かなり良い・良い・変わらない・悪くなった

質問 3.くしゃみの改善度はいかがですか? 回答：かなり良い・良い・変わらない・悪くなった 質問 4. 日常生活の支障度はいかがですか？ 回答：かなり良い・良い・変わらない・悪くなった

質問 5. 全体的な満足度はいかがですか? 回答 : 大変満足してる・満足している・あまり良くない

全閉塞のため検査不能であった. 検查の施行できた 37 例 の術前の平均值（吸気 / 呼気）は, 表 3 に示すように, 右側 7. $6 / 10.8 \mathrm{cmH}_{2} \mathrm{O} / 1 /$ 秒, 左側 $8.9 / 11.2 \mathrm{cmH}_{2} \mathrm{O} / 1 /$ 秒, 両側で $3.1 / 3.9 \mathrm{cmH}_{2} \mathrm{O} / 1 /$ 秒であった. これが術後は右 側 4.5/5.0 $\mathrm{cmH}_{2} \mathrm{O} / 1 /$ 秒, 左側 $4.3 / 4.8 \mathrm{cmH}_{2} \mathrm{O} / 1 /$ 秒, 両 側でも $1.9 / 2.2 \mathrm{cmH}_{2} \mathrm{O} / 1 /$ 秒と改善がみられた. 前述の 術前完全閉塞例 4 例の術後の平均值は右 $3.4 / 3.8 \mathrm{cmH}_{2} \mathrm{O} /$ $1 /$ 秒, 左 $4.6 / 5.5 \mathrm{cmH}_{2} \mathrm{O} / 1$ /秒, 両側でも $2.0 / 2.2 \mathrm{cmH}_{2} \mathrm{O}$ / 1/秒となり，その他の症例と大差のない值に改善した.

術後の状態に関するアンケート結果 : 術後約 1 カ月で 患者の満足度を確認するために施行したアンケートの結 果（図 4), 鼻閉に関しては全員が良い以上で，かなり良 い(51\%) が半数を占め, 術後の状態に満足が得られて いた. 鼻水, くしゃみに関しても半数以上が大変良いと 回答しており術前と変わらないと答えたものは鼻汁で 1 人，くしゃみで 4 人で悪くなったと回答したものはいず れの項目でもみられなかった. 全体的にみて 1 人を除き 全員がこの手術結果に満足していると回答した.

手術に関するアンケート：手術中の痛みに関して約半 


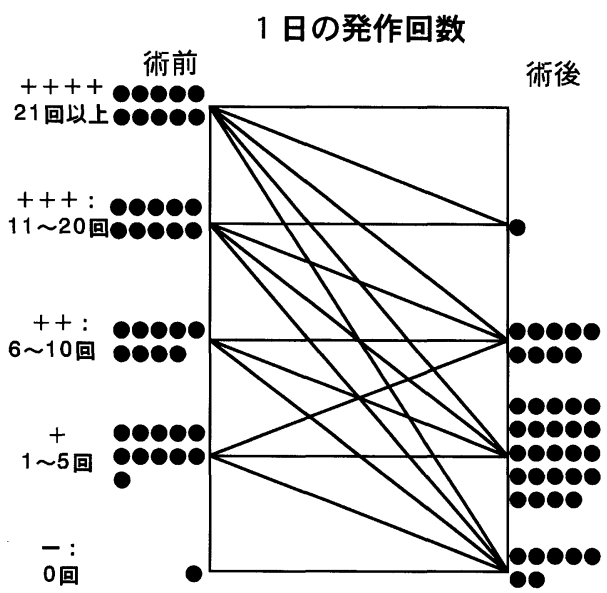

\section{症状の改善程度}

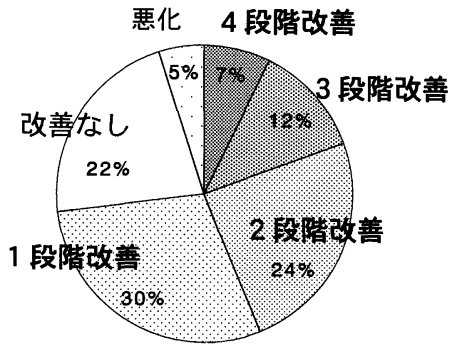

平均改善度 : 1.4 段階

図 11 日のくしやみ発作回数の術前後の比較と改善程度

術前症状は段階 3 以上が 20 人 (49\%) 症例であったのに対し，術後は 40 人（98\%） が 2 以下となった. 18 人 (43\%) で 2 段階以上の改善がみられており, 平均でも 1.4 段階の改善がみられた。

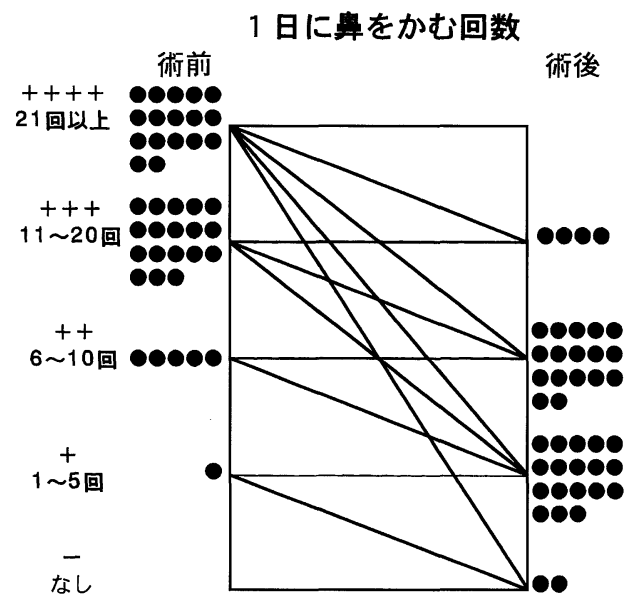

\section{症状の改善程度}

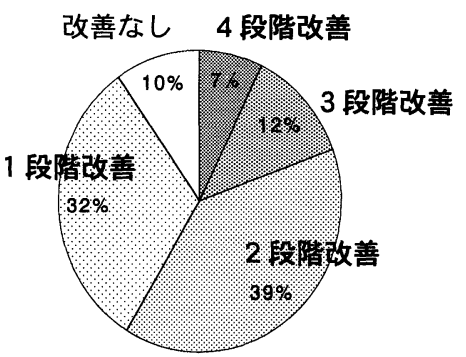

平均改善度 : 1.8 段階

図 21 日に鼻をかむ回数の術前後の比較と改善程度

術前症状が段階 3 以上であった人が 35 人（85\%）であったのに対し，術後は 37 人 (90\%) が 2 以下に改善している. 24 人 $(59 \%)$ で 2 段階以上の改善がみられており, 平均でも 1.8 段階の改善がみられた。

数は多少痛いと答えたが半数は気にならないと答えてい る.また術後の痛みに関しても $60 \%$ がほとんど気になら ないと答えている（図 5).

手術自体に関してのアンケートの結果 (図 6) では, 手 術時間については $80 \%$ 近くの症例が適当だと感じ，9人 $(22 \%)$ が長いと感じたようである. 入院日数に関しても 約 $80 \%$ が適当と感じており， 8 人 $(20 \%)$ が長いと感じ たと答えていた．費用については 9 人（22\%）は思った より安いと回答しており, 高いと思うと答えた 7 人（17
\%）を上回っていた. 残りの $60 \%$ 程度は妥当な負担と感 じたと答えている.

\section{考察}

近年アレルギー性鼻炎の有病率は増加の一途をたど り，それに含まれる重症例も増加の傾向をみせてい る4)5). 各種の抗ヒスタミン剤, 抗アレルギー剤の開発, これらを用いた初期治療の普及はアレルギー性鼻炎の治 療において大きな効果1) 3)6) を上げているが，十分な効 

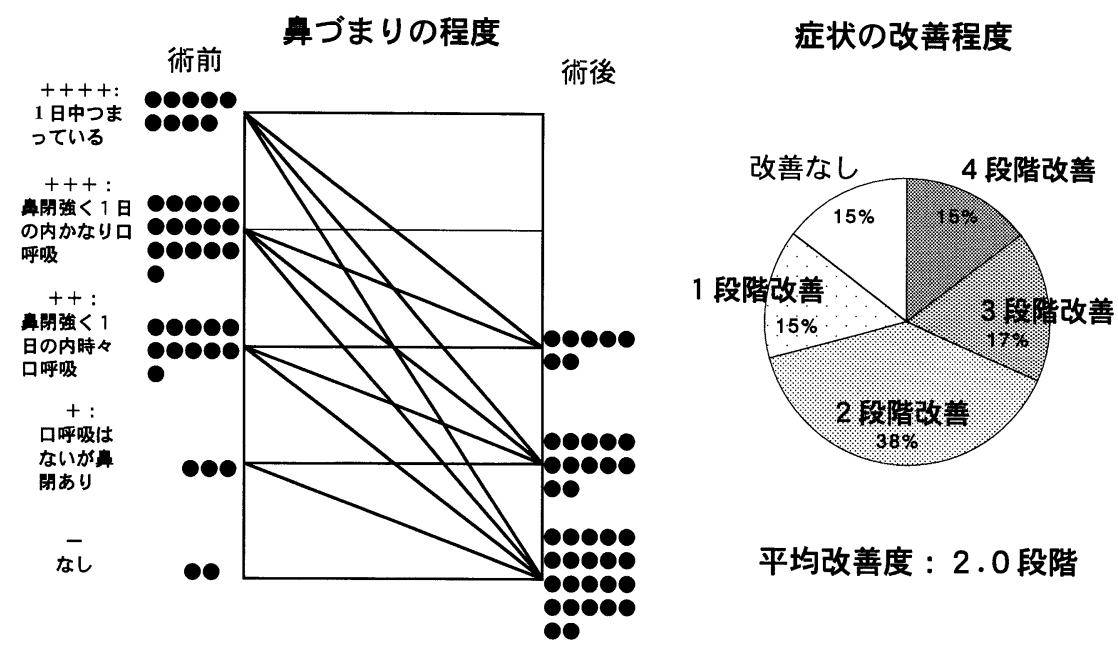

図 3 鼻づまりの程度の術前後の比較と改善程度

術前症状は段階 3 以上が 25 人（61\%）であったのに対し，術後は全員が 2 以下に なり 34 人 $(83 \%)$ は 1 以下， 24 人 $(59 \%)$ は 0 にまで改善している. 29 人（71 \%) で 2 段階以上の改善がみられ，平均でも 2.0 段階の改善がみられた.

質問 $1 ：$ 鼻閉

質問 $2:$ 鼻水

質問3：くしゃみ
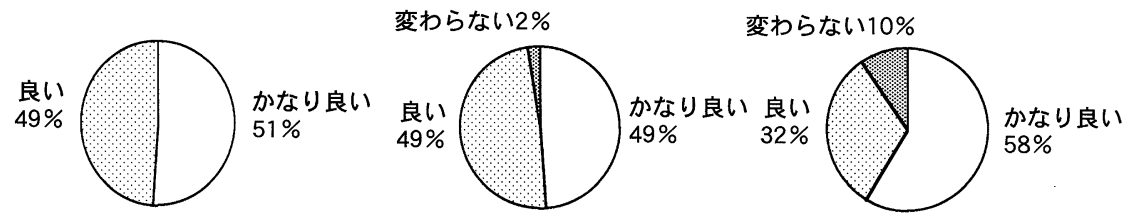

質問4：日常生活の支障度

質問 5 : 満足度
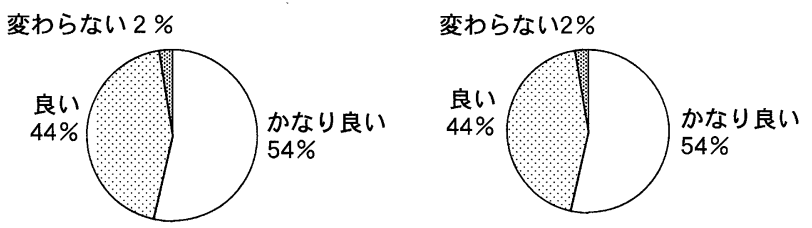

図 4 術後の状態に関するアンケート結果

鼻閉に関しては，全員が良い以上で，かなり良い $(51 \%)$ が半数を占め，鼻水，く しやみに関しても半数以上がかなり良いと回答しており,術前と变わらないと答え たものは鼻水で 1 人, くしゃみで 4 人で覀くなったと回答したものはいずれの項目 でもみられなかった。

果が得られない症例が存在することもまた事実である. 以前から重症なアレルギー性鼻炎に対しては外科的な治 療 ${ }^{8)}$ が考案され施行されてきた. 現在行われている手術 療法はヴィディアン神経切除に代表される鼻粘膜支配自 律神経切断術と下鼻甲介粘膜に対する下鼻甲介手術に大 別される. ヴィディアン神経切除はその侵襲と効果の碓 実性などを考慮すると適応はかなり限定されてしまう.
また下鼻甲介手術には下鼻甲介粘膜広範囲切除術，電気 凝固法，凍結手術，下鼻甲介化学剤手術などが考案され 施行されてきた。しかしいずれも侵襲の問題や，術後の 腫脹，痂皮形成の問題，また根治療法でないため効果の 持続時間の問題などそれぞれの方法に欠点がみられ，必 ずしも普及していない，近年普及しつつあるレーザー下 鼻甲介治療はまずその侵襲の少なさ，手術合併症の危険 
質問 $1 ：$ 手術中の痛み

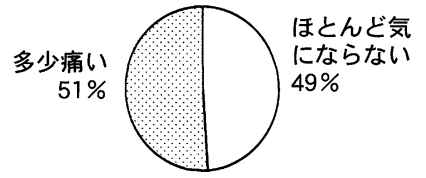

質問 $2:$ 術後の痛み

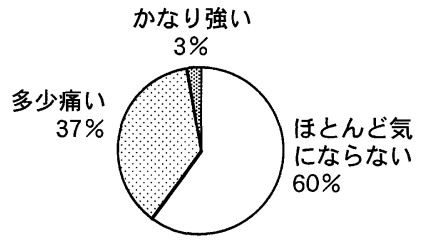

図 5 痛みに関してのアンケート結果 約半数は多少痛いと答えたが半数は気にならないと答えている. また 術後の痛みに関しても $60 \%$ がほとんど気にならないと答えた。

質問 1 : 手術時間

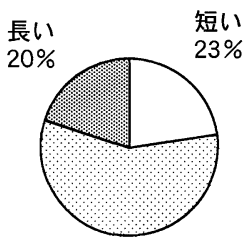

$57 \%$ 気にならない
質問 2 : 入院日数

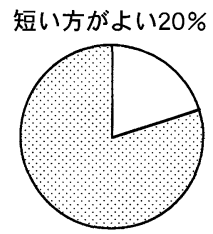

80\%ちょうど良い
質問 3 ：費用

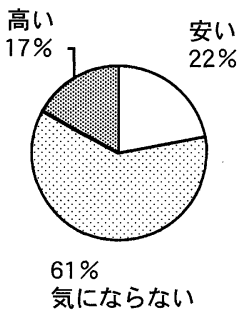

図 6 手術自体に関してのアンケート結果

手術時間については $80 \%$ 近くの症例が適当だと感じ，9人 $(22 \%)$ が長いと 回答した. 入院日数について約 $80 \%$ が適当と感じており，8人 $(20 \%)$ が長 いと感じたと答えた. 費用については 9 人 $(22 \%)$ は思ったより安いと回答 しており，高いと思うと答えた 7 人（17\%）を上回っていた. 残りの $60 \%$ 程 度は妥当な負担と感じたと答えた。

表 3 鼻腔通気度の変化

吸気 / 呼気 $\left(\mathrm{cmH}_{2} \mathrm{O} / 1 /\right.$ 秒 $)$ の平均值

\begin{tabular}{c|c|c}
\hline \hline \multirow{2}{*}{ 右側 } & 術前 & 術後 \\
\cline { 2 - 3 } & $7.6 / 10.8$ & $4.5 / 5.0$ \\
\hline \multirow{2}{*}{ 左側 } & (測定不能) & $(3.4 / 3.8)$ \\
\cline { 2 - 3 } & $8.9 / 11.2$ & $4.3 / 4.8$ \\
\hline \multirow{2}{*}{ 両側 } & （測定不能） & $(4.6 / 5.5)$ \\
\cline { 2 - 3 } & $3.1 / 3.9$ & $1.9 / 2.2$ \\
\cline { 2 - 3 } & (測定不能) & $(2.0 / 2.2)$
\end{tabular}

術前の鼻腔通気度検查で4例が完全閉塞のため検査不能で あった, 検査の施行できた 37 症例の術前の平均值 (吸気/呼気) と術後の平均值を示す. 術前完全閉塞例 4 例の術後の平均値を ( ) 内に示す.

性の少ないことで実地医家に受け入れられ, その効果が 確認されている8) 10116) 23). なかでも炭酸ガスレーザー
はその歴史も比較的古く11116) 近年器械もコンパクトにな り, 価格も低下しており導入が比較的容易なこともあり， 今後の普及が期待されている. YAGレーザー10)17) 19）と 比較して繁散が浅く，比較的出血などの合併症がなく外 来で安全かつ簡便に施行できる11) 1319)20)22)23) ことが知 られている．その反面で蒸散範囲が不十分であったり深 度が浅いため, 蒸散後に鼻閉などの症状の改善が不十分 で，1 度の蒸散では十分な効果が得られないため日を改 め何回かの焼灼を必要としたり 11)12)，比較的短期間で効 果が消失してしまい，再度治療を必要とすることも8)131 指摘されている.

今回われわれは，これらの炭酸ガスレーザーによる治 療の問題点を補うため, 下鼻甲介に可能な限り広範にむ らなく照射し，十分な蒸散深度を得るために 1 度の施行 で複数回の蒸散を考慮した. そのために，前投薬を施行 し手術室で仰臥位で各種モニターを装着し全身管理下 
に，患者の希望の音楽 $\mathrm{CD}$ を流しリラックスしてもらい， 内視鏡を用いて十分な時間を办け蒸散後に表面のカーボ ンを落とし 3 回蒸散することとした。蒸散が広範で深い ため下鼻甲介の反応性の肥厚と痂皮形成により，翌朝は ほぼ完全に閉塞した状態となる症例が多く下鼻甲介の癒 着の防止や治癒促進のためにも 2,3 日間は連日 $1 \sim 2$ 回 の鼻処置を必要とすることが多かった。また現在まで， 術後出血については安静と血管収縮片の点鼻のみでコン トロール可能で, 術後出血にて夜間処置した症例は 1 例 もなかった。しかし手術当日は，血性の浸出液がみられ 完全鼻閉塞となる症例が多く, 在宅では十分安静を保持 することが困難であったり, 患者の不安感の解消, 翌日 の外来通院の煩雑さを回避する等のために, 2 泊 3 日の 入院を基本として希望により短縮，延長可能とした。 実 際に本人の希望で入院期間を短縮した症例は，わずか 2 例であった。術後のアンケートでは, 入院期間短縮を希 望した症例が 8 例あったが，現時点までの症例で術後経 過をみる限りでは, 退院後の自宅安静が保持できて, 翌 日の外来通院が可能であれば, 今後は入院期間の短縮, 外来功の日帰り手術も可能であると考えている.

入院することで外来治療に比較して, 費用の問題が考 慮されるが，試算の結果では外来通院で 3 回再診で焼灼 を施行した場合には大差のない費用となりこれれ片側 ずつ施行した場合には本方法の方が安価となる。しかし， 今回のアンケートでは $17 \%$ で費用は高いと答えており, 今後, 今回点滴していた抗生剂を内服に変える, 入院期 間を短縮するなどで，費用の削減は可能であると考えて いる. 患者のニーズの面からみても, 本方法は外来通院 による複数回の焼灼がその生活形態から時間的に困難な 症例に対しては，有用な方法ではないかと考えている。

効果の判定は鼻内の痂皮形成がほぼなくなる 1 カ月後 を目安に外来で施行した。季節性の症例では, 季節前に 焼灼を施行しているので, 判定は症状の出る季節の終盤 から終了後に判定をした。 季節性アレルギー性鼻炎の重 症度判定を用いた問診による評価では, 予想通りに鼻閉, 鼻汁，くしゃみの順で効果が認められた。 なかでも鼻閉 については（図 3), 全員が中等度以下（段階 2 以下）の 症状に改善し，半数以上（24人 $59 \% ）$ は鼻閉がなし (0) までに改善している。 $70 \%$ 以上（29人）で 2 段階以上の 改善がみられており，平均でむ 2.0 段階の改善がみられ ている。鼻閉症状の改善がみられなかったのは最初から 鼻閉のなかった 2 例を除くと 4 例（術前症状 2 が 3 例,
術前 1 が 2 例）で，これはいずれも症状がそれほど重度 でない症例で，鼻閉の強い（段階 3，4）症例は全例改善 を認めている. 実際に鼻腔通気度検查でも術前は完全閉 塞であった 4 例もその他の症例と同等までに改善してい る. 術後のアンケートでも鼻閉については全例で満足が 得られており，本方法は鼻閉，特に重症な症例に関して 有効な方法であることが確認された。各種のレーザーを 用いた治療成績の報告11)13117)19222) においては，5～15\% 程度の無效症例の存在が報告されている。本方法は, 鼻 閉について全症例で術後の満足が得られており, 全般的 にも1例を除いた $98 \%$ の症例で手術に関する満足感が得 られている，各報告により観察期間，評価方法がそれぞ れ異なるため, 直接的な比較は困難であるが, 本方法は 他のレーザー治療の結果報告と比較しても十分高い勃果 を上げているものと思われる。

病理組織学的に蒸散後の下鼻甲介の変化を検討したと ころ, 本方法の 1 回蒸散では, 過去の文献811) と同様に, 上皮層のみにとどまる部位から一部上皮下浅層にかかる 程度の変性がみられたが，梁度はばらつきが多かった。 これに比較し 3 回蒸散した検体では一部，上皮下浅層は 腺組織む含めむらなく蒸散され，一部は深層の腺組織に も変性がみられた（図 7)。組織学的にみても確実な蒸散 が確認された。

また花粉症患者では最長で 2 シーズンの経過観察でめ るため, 花粉飛散量の違いにより必ずしも評価は困難で はあるが,今のところ燒灼前のシーズンと比較して問診,

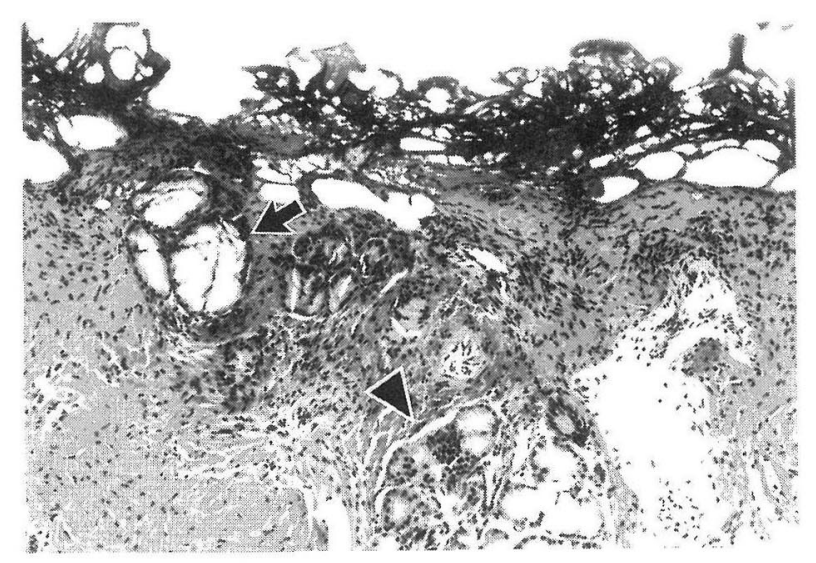

図 73 回蒸散した下鼻甲介の組織像（HE 染色， $20 \times 10 ）$ 粘膜上皮および上皮下浅層は腺組織も含め（矢印）むら なく蒸散され, 一部は深層の腺組織 (矢尻) にも変性が みられた。 
アンケートによる症状は軽減されているとの評価を得て おり，他施設の結果19) もあわせ季節性の症例にあっても 重症例が増加するなか，今後考慮されるべき治療法の 1 つとなるものと思われた。

全体的にみて症状の軽い症例において, 症状の改善度 も低く満足度も低い傾向がみられ，今後はやはり保存的 治療を十分行らなかで, 重症な症例を選択し手術適応を 決めていくことがこの方法の有用性をさらに高めるもの と考えている.

現在, 術後最長で約 2 年が経過し, 再燒灼を必要とし た症例はないが，今後さらに症例を積み重ね，適応の選 択基準および効果と費用に関しての検討を続け，術後の 長期予後についても観察したいと考えている.

\section{まとめ}

1. 局所麻酔下に内視鏡下下鼻甲介炭酸ガスレーザー治 療（3 回蒸散術）を施行したアレルギー性鼻炎患者 41 症 例につき検討した。

2. 術後の評価をアレルギー性鼻炎重症度分類による症 状の変化, 術後のアンケート, 鼻腔通気度検查により行っ た.

3. 1 度の手術でほぼ全症例においてアレルギー症状全 般的に改善し患者の満足が得られた。 なかでも鼻閉につ いては高い効果が確認された。

4. 手術時の疼痛, 入院日数, 費用などの点でもおおむ ね患者の満足が得られた。

5.内視鏡を用いた炭酸ガスレーザー治療は鼻閉に苦し む重症なアレルギー性鼻炎に対して特に有効であると考 えられた。

\section{参考文献}

1）宮本昭正：第 1 章アレルギー性疾患と第 2 世代抗ヒスタミ ン薬. アレルギー治療の新時代 (宮本昭正編). $2 \sim 13$ 頁, エムディエス株式会社, 東京, 2001.

2）竹中 洋 : 薬物療法. 現代医療（増刊） $31: 65 \sim 70,1999$.

3）馬場廣太郎, 吉田博一, 佐藤成彦 : スギ花粉症の初期治療 法. JOHNS $10: 369 \sim 373,1994$.

4）鼻アレルギー診療ガイドライン作成委員会 : 疫学. 鼻アレ ルギー診療ガイドライン (作成委員会編). 6 〜 頁, ライ フサイエンスメディカ, 東京, 1999.

5）湯田厚司 : 疫学・有病率, 加齢, 増加の原因. 現代医療 31 ： $21 \sim 26,1999$.

6）今野昭義, 山越隆行, 臼井信郎：ONO-1078（プランルカス
卜水和物）通年性鼻アレルギーに対する臨床評価, 鼻腔通 気抵抗を指標とした臨床薬理学的試験（プラセボを対象と した二重盲検比較試験)。臨床医薬 $13: 1921 \sim 1939,1997$.

7) 中之坊学：手術療法. 現代医療（増刊） $31: 77 \sim 81,1999$.

8）塞田市世：鼻アレルギーに対する下甲介レーザー手術. JOHNS $10: 375 \sim 381,1994$.

9) 大山 勝: 鼻アレルギー治療の適応と実際. 耳鼻咽喉科レー ザー医療の新しい展開（大山 勝編）. $35 \sim 41$ 頁, 金原出 版, 東京, 1997.

10) Janda $P$, Sroka $R$, Baumgartner $R$, et al. : Laser treatment of hyperplastic inferior nasal turbinate; a review. Laser Surg Med $28: 404 \sim 413,2001$.

11) Fukutake $T$, Yamashita $T$, Tomoda $K$, et al. : Laser surgery for allergic rhinitis. Arch Otolaryngol Head Neck Surg $112: 1280$ $\sim 1282,1986$.

12) Kawamura S, Fukutake T, Kubo N, et al. : Subjective results of laser surgery for allergic rhinitis. Acta Otolaryngol Suppl 500: $109 \sim 112,1993$.

13）宇井直也, 春名眞一, 鴻 信義, 他: 鼻閉に対する外来 $\mathrm{CO}_{2}$ レーザー治療の効果. 耳展 $42: 514 \sim 518,1999$.

14）鼻アレルギー診療ガイドライン作成委員会 : アレルギー性 鼻炎の分類. 鼻アレルギー診療ガイドライン（作成委員会 編). $14 \sim 22$ 頁, ライフサイエンスメディカ, 東京, 1999.

15）大久保公裕, 奥田 稔：アレルギー性鼻炎の症状と新重症 度分類，QOL 評価. 現代医療（増刊） $31 ： 39 \sim 46,1999$.

16) Mittelman $\mathrm{H}: \mathrm{CO}_{2}$ laser turbinctomies for chronic, obstructive rhinitis. Laser Surg Med $2: 29 \sim 36,1982$.

17）伊藤浩隆，鈴木元彦，間宮紳一郎，他：アレルギー性鼻炎 に対する Nd； YAG レーザー治療の効果. アレルギー 44 ： $93 \sim 95,1995$.

18) Jovanovic $S$ and Dokic $D$ : Does laser turbinectomy influence local allergic inflammation in the nose? Rhinology 34:46 49, 1996.

19) Lippert B and Werner JA : Long-term results after laser turbinectomy. Lasers Surg Med 22: $126 \sim 134,1998$.

20) Terada N, Hamano N, Terada Y, et al. : Changes in nasal responsiveness to histamine and to specific antigen after laser surgery. Acta Otolaryngol Suppl 537 : 38 42, 1998.

21) Inouye $T$, Tanabe $T$, Nakanoboh $M$, et al. : Laser surgery for allergic and hypertrophic rhinitis. Ann Otol Rhinol Laryngol Suppl $180: 3 \sim 19,1999$.

22) Tanigawa T, Yashiki T, Hayashi K, et al. : Carbon dioxide laser vaporization for turbinate; optimal conditons and indications. Auris Nasus Larynx $27: 137 \sim 140,2000$.

23）飛田 正, 三島陽人, 加藤康弘, 他：下鼻甲介前方切除術 に関する臨床的研究. 日耳鼻 $104: 663 \sim 667,2001$.

原稿受付：平成14年 1 月 25 日

原稿採択：平成14年 3 月 27 日

別刷請求先 : 今村俊一

厂 390-8621 松本市旭3-1-1

信州大学医学部耳鼻咽喉科学教室 